\title{
Naked-neck and frizzled feather fowls are high performance laying local chicken in
} Nigeria

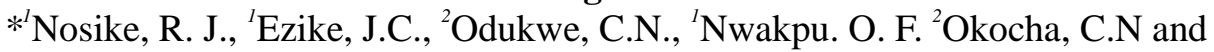
${ }^{2}$ Onunkwo, D.N.

${ }^{l}$ Department of Animal Breeding and Physiology, Michael Okpara University of Agriculture, Umudike, Abia State, Nigeria

${ }^{2}$ Department of Animal Nutrition and Forage Science, Michael Okpara University of Agriculture, Umudike, Abia State, Nigeria

*Corresponding author: nosikereginald@gmail.com. +2348037603823

\section{Abstract}

The study was conducted to investigate the effect of genotype on the laying performance of Nigerian local chicken. The experiment was carried out using 99 local chicken of the three genotypes, comprising of 90 hens and 9 cocks (33 frizzle feather, 33 naked-neck feather and 33 normal feathered). Eggs were collected from the different genotypes for 8 weeks. The laying performance traits were egg number, hen-housed (\%) and hen-day (\%) egg production. Data collected were subjected to ANOVA in a completely randomised design. The hen-day egg production showed significant differences $(P<0.05)$ in all the weeks. Naked-neck genotype performed better in terms of hen-day egg production than the other two genotypes and had highest values in week 1 (27.14 \pm 0.01$)$, week $5(27.60 \pm 0.09)$, week 7

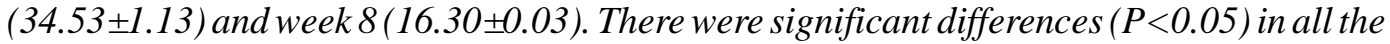
weeks for hen-housed egg production and naked-neck also performed better than the frizzled and normal feather apart from week 2, 3 and 6. The naked-neck genotype had highest mean values in week 1, 4, 5, 7 and 8 with 27.18 $\pm 0.06,25.70 \pm 0.02,19.33 \pm 0.67,24.08 \pm 0.22$ and $11.39 \pm 0.03$ respectively for hen-housed egg production. The naked-neck had significantly $(P<0.05)$ higher values for egg number when compared with frizzle and normal feathered genotypes. The values ranged between $5.67 \pm 0.67$ to $2.00 \pm 0.10$ (naked-neck), $6.33 \pm 0.33$ to $2.67 \pm 0.67$ (frizzle) and $3.33 \pm 0.33$ to $1.33 \pm 0.33$ (normal). It is therefore, reasonable to incorporate the naked-neck and frizzled feather genotypes of local chicken in producing locally-adapted commercial eggs

Keywords: genotype, local chicken, laying performance.

\section{Introduction}

The Nigeria local chicken has been found to be self reliant and hardy birds with the capacity to withstand harsh weather condition and adapt favourably. Out of the 82.4 million poultry in Nigeria, the local chickens constitute 80\% (FDLPCS, 2003). Factors such as poor pullet quality, inappropriate feeding regime, and poor farm management all constitute to the negative impact on the laying performance and egg quality of these local chicken (Hagan and Adjei, 2010). Percentage henday production is affected by several factors such as strain of birds, feeding, mortality, culling, health and management practices, age at point of lay, peak of lay and persistency (Tolimiro and Masic, 2000). Reproductive performance is a phenomenon where an animal gives acceptable level of production in a stressed environment (Ibe, 1990). Developing a poultry stock that can tolerate such environment and give acceptable level of reproduction is desirable (Nwachukwu et al., 2006).The objective of the study was therefore to determine the laying performance of the three genotypes of local 


\section{Naked-neck and frizzled feather fowls are high performance laying local chicken in Nigeria}

chicken.

\section{Materials and Methods}

The experiment was carried out at the poultry unit of this research and commercial farm of Michael Okpara University of Agriculture, Umudike, Abia State, Nigeria.

\section{Experimental birds and management}

A total number of 99 adult local chickens were selected for this experiment comprising of three genotypes with a total of 99 hens and nine cocks (33 frizzle, 33 naked-neck and 33 normal) feathered and nine cocks. The experiments were three treatments/genotypes and were replicated three times with 11 birds per replicate. The experiment lasted for a period of 10 weeks including two weeks of adaptation. Eggs were collected twice daily for eight weeks. The birds were housed in pen, open sided concrete house covered with wood shaving as a litter material. All the birds were fed $a d$ libitum on commercial feed. Fresh water was provided for drinking.

Experimental procedures

Mating System: Frizzle male x Frizzle female (F x F), Naked Neck x Naked Neck $(\mathrm{Na} \times \mathrm{Na})$ and Normal x Normal $(\mathrm{N} x \mathrm{~N})$. Mating Ratio: 10 females to 1 male in each replicate is presented in Table 1.

Table 1: Mating Scheme and Number of Eggs Produced

\begin{tabular}{llcc}
\hline Mating type & No of females & No of males & No of eggs \\
\hline $\mathrm{F} \times \mathrm{F}$ & 30 & 3 & $\mathbf{8 8}$ \\
$\mathrm{Na} \times \mathrm{Na}$ & 30 & 3 & $\mathbf{1 1 2}$ \\
$\mathrm{N} \times \mathrm{N}$ & 30 & 3 & $\mathbf{7 0}$ \\
\hline
\end{tabular}

Parameters measured

Eggs number: This was done by physical counting of eggs.

Hen-day egg production: The total number of eggs laid by each replicate group as collected twice each day. this was calculated by;

$\begin{array}{ll}\text { Number of eggs laid } & X \quad \frac{100}{1}\end{array}$

Hen housed egg production: This was calculated by;

Total No of eggs laid in a day $\quad$ X $\underline{100}$

Total No of hens housed at beginning of laying 1

Experimental design

The experiment was designed as a completely randomized design. The model for the experiment was: $Y i j=\mu+T_{i}+e_{i j}$ Where $\mathrm{Y}_{\mathrm{ij}}=$ single observation, $\mu=$ overall mean, $T_{i}=$ effects of treatment, $e_{i j}=$ Random error, assumed to be independently, identically and normally distributed with zero mean and constant variance [iind $\left.\left(0, \sigma^{2}\right)\right]$.

Statistical analyses

Data were statistically analyzed with SPSS,
2011 version 16. All the parameters were determined in percentages which were subjected to arcsine transformation to satisfy the assumption of normal distribution. Duncan's Multiple Range Test (Duncan, 1955) was used to separate significant means.

\section{Results and Discussion Effect of Genotype on the Hen-Day Egg Production (\%) of Local Chicken}

Table 2 shows the means of hen-day egg production $(\%)$ of the three genotypes of local chicken from week 1- 8. The results showed that the three genotype of local chicken differed significantly $(\mathrm{P}<0.05)$ in their hen-day egg production in all the weeks, but the naked-neck produced significantly $(<0.05)$ higher hen-day egg production in weeks $1,5,7$ and 8 than those of frizzled and normal feather. The mean hen-day values recorded were $27.14 \pm 0.01$ to $16.30 \pm 0.03$ (naked-neck), $17.15 \pm 0.33$ to $9.42 \pm 1.05$ (frizzled) and $17.34 \pm 0.08$ to $8.26 \pm 0.31$ (normal feather). The 
Nosike, Ezike, Odukwe, Nwakpu. Okocha and Onunkwo

Table 2: Mean $( \pm$ SE) Values of Hen - Day Egg Production $(\%)$ of the Three Genotypes of Local chicken (1 - 8 Weeks)

\begin{tabular}{llll}
\hline Weeks & Frizzle feather & Naked-neck feather & Normal feather \\
\hline 1 & $17.15 \pm 0.33^{\mathrm{b}}$ & $27.14 \pm 0.01^{\mathrm{a}}$ & $17.34 \pm 0.08^{\mathrm{b}}$ \\
2 & $14.28 \pm 0.02^{\mathrm{c}}$ & $20.54 \pm 0.05^{\mathrm{b}}$ & $23.08 \pm 0.01^{\mathrm{a}}$ \\
3 & $25.57 \pm 0.11^{\mathrm{a}}$ & $15.57 \pm 0.18^{\mathrm{c}}$ & $18.67 \pm 0.01^{\mathrm{b}}$ \\
4 & $33.02 \pm 0.64^{\mathrm{a}}$ & $28.57 \pm 0.02^{\mathrm{b}}$ & $18.67 \pm 0.01^{\mathrm{c}}$ \\
5 & $22.63 \pm 0.25^{\mathrm{b}}$ & $27.60 \pm 0.09^{\mathrm{a}}$ & $16.81 \pm 0.14^{\mathrm{c}}$ \\
7 & $25.67 \pm 0.20^{\mathrm{a}}$ & $20.14 \pm 0.08^{\mathrm{b}}$ & $12.80 \pm 0.13^{\mathrm{c}}$ \\
8 & $27.45 \pm 0.58^{\mathrm{b}}$ & $34.53 \pm 1.13^{\mathrm{a}}$ & $25.76 \pm 0.05^{\mathrm{b}}$ \\
\hline
\end{tabular}

${ }^{\mathrm{a}-\mathrm{c}}$ Means in the same column with different superscripts are significantly different $(\mathrm{P}<0.05)$

$\mathrm{SE}=$ Standard Error of Means

significantly better $(\mathrm{P}<0.05)$ performance in hen-day egg production of the nakedneck local chicken over the frizzled feather and normal feather confirms the observation that under constant heat stress, the naked-neck local chicken has significantly higher productivity than the frizzled and normal feather local chicken (Mathur, 2003). The better performance of the frizzle hens with regards to hen-day egg production compared with the normally feathered birds confirms the findings of Host and Mathur (1992) that when reared under high temperatures, the frizzling feathered layers performed better in terms of egg production when compared to their normally feathered groups.

Effect of Genotype on the Hen-House Egg Production (\%) of Local Chicken

Table 3 shows the means of hen-house egg production of the three genotypes of local chicken from week 1- 8. The results showed that the three genotype of local chicken differed significantly $(\mathrm{P}<0.05)$ in their henday egg production in all the weeks. The naked-neck had significantly $(\mathrm{P}<0.05)$ higher hen-house egg production in weeks $1,4,5,7$ and 8 than those of frizzled and normal feather. The mean hen-house values recorded were $27.18 \pm 0.06$ to $11.39 \pm 0.03$ (naked-neck), $17.46 \pm 0.35$ to $7.19 \pm 1.19$ (frizzled) and $17.34 \pm 0.01$ to $6.46 \pm 0.34$ (normal feather). Just like in the hen-day egg production, the significantly better $(\mathrm{P}<0.05)$ performance in hen-house egg production of the naked-neck local chicken over the frizzled feather and normal feather confirms the observation that under constant heat stress, the naked-neck local chicken has significantly higher

Table 3: Mean $( \pm$ SE) Values of Hen -Housed Egg Production $(\%)$ of the Local chicken

\begin{tabular}{llll}
\hline Weeks & Frizzled feather & Naked-neck feather & Normal feather \\
\hline 1 & $17.46 \pm 0.35^{\mathrm{b}}$ & $27.18 \pm 0.06^{\mathrm{a}}$ & $17.34 \pm 0.01^{\mathrm{b}}$ \\
2 & $10.62 \pm 0.05^{\mathrm{c}}$ & $18.36 \pm 0.11^{\mathrm{b}}$ & $21.46 \pm 0.22^{\mathrm{a}}$ \\
3 & $16.04 \pm 0.02^{\mathrm{c}}$ & $14.35 \pm 0.10^{\mathrm{b}}$ & $17.36 \pm 0.30^{\mathrm{a}}$ \\
4 & $22.58 \pm 0.88^{\mathrm{b}}$ & $25.70 \pm 0.02^{\mathrm{a}}$ & $17.41 \pm 0.07^{\mathrm{c}}$ \\
5 & $14.33 \pm 0.09^{\mathrm{b}}$ & $19.33 \pm 0.67^{\mathrm{a}}$ & $13.17 \pm 0.08^{\mathrm{b}}$ \\
6 & $16.03 \pm 0.02^{\mathrm{a}}$ & $14.27 \pm 0.02^{\mathrm{b}}$ & $9.21 \pm 0.02^{\mathrm{c}}$ \\
7 & $17.60 \pm 0.14^{\mathrm{c}}$ & $24.08 \pm 0.22^{\mathrm{a}}$ & $18.38 \pm 0.09^{\mathrm{c}}$ \\
8 & $7.19 \pm 1.19^{\mathrm{b}}$ & $11.39 \pm 0.03^{\mathrm{a}}$ & $6.46 \pm 0.34^{\mathrm{c}}$ \\
\hline
\end{tabular}

${ }^{\mathrm{a}-\mathrm{c}}$ Means in the same column with different superscripts are significantly different $(\mathrm{P}<0.05)$ $\mathrm{SE}=$ Standard Error of Means 


\section{Naked-neck and frizzled feather fowls are high performance laying local chicken in Nigeria}

productivity than the frizzled and normal feather local chicken (Mathur, 2003). And also better performance of the frizzle hens with regards to hen-house egg production compared with the normally feathered birds confirms the findings of Host and Mathur (1990) that when reared under high temperatures, the frizzling feathered layers performed better in terms of egg production when compared to their normally feathered groups.
Effect of Genotype on Egg Number of the Three Genotypes of Local Chicken

Table 4 shows the means of egg numbers of the three genotypes of local chickens from weeks 1-9. The results indicated significant difference $(\mathrm{P}<0.05)$ in egg numbers for the various weeks. From the table, the nakedneck genotype of local chicken produced significantly $(\mathrm{P}<0.05)$ higher egg numbers than those of frizzled and normal feather genotypes which were evident in weeks 2 ,

Table 4: Mean ( \pm SE) Values of Egg Number of the Three Genotypes of Local Chicken

\begin{tabular}{lccc}
\hline Weeks & Frizzled feather & Naked-neck feather & Normal feather \\
\hline 1 & $6.33 \pm 0.33^{\mathrm{a}}$ & $5.67 \pm 0.67^{\mathrm{a}}$ & $3.33 \pm 0.33^{\mathrm{b}}$ \\
2 & $4.33 \pm 0.33^{\mathrm{b}}$ & $7.00 \pm 0.58^{\mathrm{a}}$ & $2.00 \pm 0.00^{\mathrm{c}}$ \\
3 & $3.33 \pm 0.33^{\mathrm{b}}$ & $5.67 \pm 0.67^{\mathrm{a}}$ & $3.00 \pm 0.00^{\mathrm{b}}$ \\
4 & $6.00 \pm 0.58^{\mathrm{a}}$ & $5.67 \pm 0.67^{\mathrm{a}}$ & $4.00 \pm 0.58^{\mathrm{c}}$ \\
5 & $4.67 \pm 0.67^{\mathrm{a}}$ & $4.33 \pm 0.88^{\mathrm{b}}$ & $2.67 \pm 0.33^{\mathrm{c}}$ \\
6 & $3.33 \pm 0.88^{\mathrm{a}}$ & $3.00 \pm 0.58^{\mathrm{b}}$ & $3.00 \pm 0.58^{\mathrm{b}}$ \\
7 & $5.67 \pm 0.67^{\mathrm{a}}$ & $6.00 \pm 0.58^{\mathrm{a}}$ & $3.33 \pm 0.33^{\mathrm{b}}$ \\
8 & $2.67 \pm 0.67^{\mathrm{a}}$ & $2.00 \pm 0.10^{\mathrm{b}}$ & $1.33 \pm 0.33^{\mathrm{c}}$ \\
\hline a-c Means in the same column with different superscripts are significantly different $(\mathrm{P}<0.05)$ \\
SE = Standard Error of Means
\end{tabular}

3,7 and 9. The values recorded were $5.67 \pm 0.67$ to $2.00 \pm 0.10$ (naked-neck feather), $6.33 \pm 0.33$ to $2.67 \pm 0.67$ (frizzled feather) and $3.33 \pm 0.33$ to $1.33 \pm 0.33$ (normal feather). Younis and Cahaner (2005) reported that at high ambient temperature, the frizzle hens had deterioration in egg productivity and quality comparable to that of normally feathered birds, suggesting that the frizzle gene may not be as well adapted to heat stress as the naked-neck. One reason could be that unlike the naked neck, the overall feather mass of frizzle birds is not significantly reduced when compared to the normally feathered ones. Cahaner et al., (1993) indicated that the reduction of feather coverage provides relative heat tolerance and therefore, at high ambient temperature, naked-neck chickens are superior to their normally feathered counterparts.

\section{Conclusion}

From the results of this experiment, it can be concluded that among the three genotypes of local chicken studied, the naked-neck genotype of local chicken has superior and better performance in egg laying followed by frizzled feather genotype. It could also be concluded from this study that the naked-neck feather genotype laid more eggs than the other genotypes. The naked-neck genotype could be recommended as an ideal and suitable genotype of local chicken for egg production. There is also a need to conserve and preserve the naked -neck and frizzled 
feather local chicken so that they could be used in future breeding program.

\section{References}

Cahaner, A., Yunis, R., and Zith, A. H. 1993. Adaptation of frizzle and naked-neck gene to hot humid conditions. Poult sci. 71: 13471352.

Hagan J.K. and I. A. Adjei. 2010. Evaluation of productive performance of crossbred nakedneck and frizzle chicken genotypes. Unpublished PhD thesis. KNUST, Kumasi, Ghana.

Ibe, S.N. 1990. Utilising local poultry genetic resources in Nigeria Proc. 4th World Congress on Genetics Applied to Livestock Production, Edinburgh, Scotland. 14:51-53.

Mathur, P.K. and P. Horst, 1990. Single and combined effects of tropically relevant major genes on performance of layers. Proceedings of the 4th Congress on Genetics Applied to Livestock Production, July 23-27, Edinburgh, Pp: 131-134.
Mathur, P. K. 2003. Genotypeenvironment interactions: Problems associated with selection for increased production. In; Poultry Genetics, Breeding and Biotechnology edited by M.W. Muir and S.E. Aggrey. CABI Publishing, UK, P. 546.

Nwachukwu, E. N., Ibe, S.N., Ejekwu, K and Oke, U. K. 2006. Evaluation of the growth parameters of main and reciprocal normal, naked neck and frizzled chicken in a humid tropical environment. J. Anim. Vet. Adv. 5:542-546.

SPSS 2011. Statistical Package for Social Sciences. SPSS Inc.(16.0), 444 Michigan Avenue, Chicago.

Tolimoro, N. and Masic, B. 2000. The result of European egg production test in 1997-1998. Zivimarstov. 35(5):66-68.

Yunis, R., Cahaner, A. 2005. Effect of the naked neck $(\mathrm{Na})$ and frizzle $(\mathrm{F})$ genes on growth and meat yield of broilers and their interaction with ambient temperature and potential growth rates. Poult sci. 78: $1347-$ 1352.

Received: 8th July, 2017

Accepted: 30th November, 2017 